\title{
Arbor
}

\section{Salamanca, ciudad fronteriza}

\author{
Luciano G. Egido
}

Arbor CLXXIII, 683-684 (Noviembre-Diciembre 2002), 459-468 pp.

Cuando el viejo topónimo prerromano de Salamanca se convirtió en signo universal estaba en marcha el proceso de la secularización de la cultura, ensayando la experiencia de la frontera desde muy temprano. Este punto de partida determinaría todo el desarrollo semántico del nombre, que recibiría las sucesivas trasformaciones y acomodaciones, que la cosecha de los nuevos tiempos le iría trayendo. Esta marcha no se apartará en nada de lo que ha ocurrido en general en otros ámbitos geográficos y en otras circunstancias históricas. Quizá lo específico de Salamanca sea la claridad con que se ordenan sus elementos y la facilidad de lectura de sus manifestaciones. Sería obtuso y tentador reunir las razones de estas evidencias, desde los motivos de los primeros asentamientos humanos en las dos colinas matrices de la ciudad, en la frontera de dos formaciones geológicas distintas, que darían origen a la contradicción básica de las dos Salamancas económicas, la cerealista y la ganadera, o su posición lingüística entre los reinos de León y de Castilla, hasta su creación medieval en la línea misma divisoria entre los dominios árabe y cristiano, en la indecisa separación de dos concepciones diferentes de la vida. Pero probablemente esto sería un abuso dialéctico y caer en la tentación del reduccionismo perezoso de la generalización. Que no están los tiempos para el determinismo mágico del naturalismo filosófico y del viejo simplismo positivista decimonónico. Además como la cultura en todas partes ha sido flor de la frontera, en Salamanca no podía ser menos.

Está por ver la razón última del traslado de los Estudios Generales de Palencia a Salamanca, a principios del siglo XIII, que sería el punto cero de su significación cultural. Posiblemente habría varias motivaciones convergentes, que moverían al rey don Alfonso IX a decidir 
trasformar la escuela catedralicia salmantina en centro de preparación profesional para dotar al reino de la infraestructura jurídica necesaria para su vertebración política. En la elección del lugar intervendría su fidelidad sentimental al lugar de su nacimiento; pero también su posición en la extremadura leonesa, el imperativo de densificar la repoblación de aquel sur, siempre amenazado, las características ambientales de aquel villorio, dotado de buen agua, de buenos y deleitosos alrededores y del silencio óptimo para el estudio, como tantas veces se ha repetido. Pero fuera cual fuese la razón de aquella localización, el hecho es que aquella decisión real le daría un nuevo destino a Salamanca, que al parecer todavía le dura. Desde aquella fecha de 1218 , la ciudad se haría la sede de una Universidad, que contaría entre los grandes centros universitarios de la cristiandad y que después de múltiples avatares llegaría hasta nosotros con los mismos signos, aunque con otras características, que asentaron su fama desde la Edad Media. No siempre estuvo a la altura de su nombre e incluso en algunas ocasiones estuvo a punto de perecer; pero nunca dejó de ser, ni en sus peores momentos, la representación de la cultura y probablemente por eso sufrió tantos altibajos y tantas desorientaciones. Porque todas las fronteras están sometidas a estas vejaciones.

Salamanca frontera y Salamanca cultura forman un binomio ineludible. La historia de la cultura española con todos sus adherentes conflictivos y la historia de Salamanca con sus vaivenes dramáticos corren paralelas, en una mutua réplica prácticamente sin fisuras. La secularización de la cultura medieval, la irrupción de las nuevas ideas del llamado Renacimiento, la ilusión fantasmagórica de la época barroca, la batalla del racionalismo de la Ilustración, la decadencia decimonónica y el regeneracionismo del 98 y sus últimas consecuencias tuvieron en Salamanca su fiel repercusión y, si nos atrevemos a apurar el concepto, su versión arquitectónica y por supuesto urbanística. Ya el prof. Apráiz señaló el orientalismo de una parte de la arquitectura salmantina y Unamuno escribió sobre la impresión bizantina del alto soto de torres de la ciudad, a la hora del crepúsculo. La historia del Arte, como parte de la Historia de la cultura, puede también testimoniar de esta identificación de Salamanca con las manifestaciones más esenciales de cada situación histórica. El románico agónico y el gótico póstumo, el renacentismo italianizante, el contrarreformismo jesuítico, los excesos del barroquismo, la racionalidad del Siglo de las Luces, el modernismo novecentista y la simplicidad de una buena parte de la estética actual son como notas a pie de página de esa evolución cultural de la ciudad universitaria española por excelencia y naturalmente por antonomasia. 


\section{Salamanca, ciudad fronteriza}

Hasta tal punto esta fidelidad histórica a la cultura de cada tiempo, que tiene en la Universidad el eje de su desarrollo, es demostrable, que se puede establecer la nómina de sus protagonistas y su incidencia en la permanente revitalización del topónimo cultural, que ya no será el nombre de un lugar, sino la denominación de una idea, la rehabilitación de unas tradiciones del pensamiento y de la literatura y la confirmación perpetua de los valores de un signo de la cultura. Nombres, como los de fray Luis y Unamuno, para tomar sólo los símbolos estelares de la Universidad, son suficientes para hacer ver la adscripción de Salamanca a lo que la cultura tiene de espíritu fronterizo y de dramática peligrosidad.

Desde muy temprano, cuando en la península ibérica ni siquiera se había adquirido el concepto de nacionalidad, Salamanca fue creando un ámbito de preocupaciones culturales, que generarían sus propias tradiciones y hasta cierto punto predeterminarían su desarrollo futuro. La ciudad adquiriría en la Baja Edad Media una personalidad diferencial, producto de su dedicación universitaria, habitada, junto a los nativos, por gentes heterogéneas, venidas de todas partes, que traerían en su equipaje modos y conductas, que conformarían un choque de experiencias, que le darían un aire distinto. Los textos literarios de los primeros siglos de la Universidad salmantina testimonian sobre la conciencia ciudadana de asombro y rechazo de estos extraños componentes de su realidad urbana. Las anécdotas, incluso sangrientas, causadas por esta tensión entre forasteros y naturales del país, son frecuentes en aquel tiempo. Los universitarios — profesores y escolareseran considerados enemigos y, desde luego, como extranjeros no asimilados a la comunidad ruralizada de los años iniciales. Los orígenes de la leyenda de la Cueva de Salamanca hay que pensar que estuvieron relacionados, aunque lloviera sobre el mojado de la historia, con este distanciamiento de los salmantinos de la época respecto al hecho inquietante, misterioso, pecaminoso y amenazante del cultivo de algo tan inasequible como la cultura, al que el empleo escolar del latín, ya olvidado, daría más pábulo a la imaginación medrosa de los excluidos. Porque existieron dos Salamancas paralelas, que perpetuaron durante muchos siglos sus resquemores y sus desconfianzas.

Este aislamiento social de la cultura nos ofrece una primera aproximación al tema del simbolismo cultural salmantino, que ha mantenido su vigencia dialéctica. Porque toda sociedad establecida y organizada, que conserva vivos los recursos de su supervivencia, teme por la sospechosa erupción de la cultura. Los famosos «cabezas de huevo» han gozado del perpetuo desprecio de la sociedad norteamericana, que ve 
con malos ojos el crecimiento de unos elementos disconformes, disidentes e inasimilables, como debieron serlo para aquellos salmantinos medievales, que se sintieran invadidos por aquel aluvión de tipos raros, que ni en sus vestidos, ni en su vocabulario ni en su género de vida eran como ellos y a los que con facilidad y con alivio demonizaron, como hijos del demonio. El hecho de que, por otra parte, se aprovecharan de cuantiosos privilegios fiscales y tuvieran encima la paternal protección de los reyes, que tanto los necesitaban, aumentaría su antipatía social y los aureolaría con todos los defectos de la alteridad. Es fácil comprender el impacto en aquel núcleo rural, salido penosamente de la coacción feudal, sostenido e identificado por sus propias tradiciones morales, económicas y domésticas, de aquellos nuevos habitantes con los que tenían que compartir el espacio urbano, tan arriesgadamente alcanzado, inclasificables, fuera de sus expectativas vitales y además irreductibles e impermeables a todo lo que no fueran sus libros, sus pensamientos esotéricos y la linealidad racional de sus discursos, por lo demás incomprensibles. Pero lo que sería el colmo de la desfachatez era su ambigüedad funcional entre el estado eclesiástico y el estado seglar, víctimas de la secularización de la cultura, que turbaría las creencias religiosas de los lugareños.

Tampoco ellos harían nada por integrarse en aquella colectividad cerrada, que ponía en cuarentena todo lo foráneo, lo imprevisto, lo original. El tipo del estudiante, que venía de lejos y que encontró en aquella ciudad incipientemente universitaria su habitat natural, tendría la ingravidez y el desparpajo de su elitismo y acumularía insultos y denuncias, creando ese personaje descreído, fanfarrón, mujeriego, borracho, jugador y espadachín, que la literatura castellana dotaría de larga vida y que originaría su propia tradición de seres marginados, entregados a todos los excesos, incluídos los del inconformismo y el enfrentamiento con los poderes constituídos, que los hicieron protagonistas de revueltas y protestas, que jalonan la historia de la Universidad de Salamanca y que fueron más allá de los «pecados de juventud», de la excitabilidad de sus inmaduros y lábiles sistemas nerviosos y de su despreocupación ociosa y jaranera, para consentir una reflexión sobre la intransigencia moral, la rebelión como tentación permanente y la agudeza intelectual para detectar mentiras, abusos, idealizaciones espúreas y amenazas latentes, que sólo la cultura les podía hacer ver. Eran el lado espontáneo, frágil, desorganizado y visible de la tarea de la cultura, con lo que Salamanca - la ciudad del estudiante, como lo sabía Cervantes y lo seguía sabiendo Espronceda - adquirió también ese desapacible signo cultural del desasosiego, de la confrontación y del culo de mal asiento, coincidiendo en 
sus últimas consecuencias con la inquietud reivindicativa de los segundones que frecuentaron sus aulas universitarias y les proporcionarían la voracidad cainita de su ciudadanía de segundo orden, siempre detrás de los caballeros, pero antes de los campesinos.

Hemos hablado antes de la desacralización de la cultura en los momentos en que nace la Salamanca universitaria. No podía ser de otro modo y ambos hechos, como ocurrió en toda Europa, proceden del mismo tronco histórico. Con el nacimiento de las ciudades se pierde el carácter sagrado de la cultura, arrastrado por el nuevo horizonte de necesidades espirituales ciudadanas. La burguesía emergente borra su dependencia de los centros culturales eclesiásticos y exige nuevos conocimientos prácticos, que den respuesta a sus problemas, que no son los del antiguo régimen feudal. Los viejos monasterios se aislan en el campo, en las montañas o en los páramos eremíticos y son las Universidades las que reciben la herencia del saber y la ponen al servicio de la nueva sociedad. Los reyes organizan sus reinos sobre la realidad y la fuerza de los núcleos urbanos, que representan el porvenir y tienen todo el poder de sus proyectos. Salamanca se afirma en este proceso y añade un nuevo signo a su determinación esencial de frontera. De los estudios catedralicios, en los que los hijos de los burgueses se empiezan a interesar, de cara a mejorar su condición social y asegurarse su futuro, se desgajan las Escuelas, que serían el germen de la Universidad, y allí conviviría, impulsada por contradictorias apetencias, una fauna escolar de múltiples procedencias y de heterogéneas perspectivas de vida. El Derecho Canónico alternaría con los rudimentos del Derecho Civil, en los que sobrevivían los restos inalterables del Derecho Romano, precristiano. La Gramática y la Retórica ya no servirían sólo para desentrañar y perpetuar los textos de inspiración divina, sino para perfeccionar el entendimiento y la utilización, a ras del suelo, de los textos humanos. La frontera cuaja en matices. Ya no serían sólo los eclesiásticos, dedicados al pastoreo de las cosas eternas, los que frecuentaban los estudios catedralicios, primero, y las Éscuelas universitarias, después. Los hijos de la joven burguesía se interesarían también por el saber y lo entroncarían con el servicio profesional, surgido de las demandas de sus conciudadanos, burgueses como ellos. La Universidad de Salamanca nace para dotar al reino de los juristas que necesita para la vertebración de una sociedad en formación, desestructurada y, hasta cierto punto, caótica, salida del hundimiento del régimen feudal.

Aquellos primeros escolares salmanticenses, que no necesariamente ni mucho menos salmantinos, que se asomaban a las Cantigas de Santa 


\section{Luciano G. Egido}

María, de Alfonso el Sabio, con sus trapacerías ya puestas, no se habían desprendido todavía, y tardarían siglos en hacerlo, de sus orígenes culturales eclesiásticos. Vestían como clérigos, hablaban su latín culto y estaban impregnados de las secuelas de los libros sagrados. Pero eran ya laicos y la palabra «clérigo» no tenía muy delimitado su contenido semántico. Estos hombres eran hombres de frontera. Ese mismo escolar de las Cantigas, que huye de la justicia de Salamanca por haberse calzado a la mujer de otro, nos puede servir para ejemplificar la situación de estos escolares del siglo XIII. Su devoción mariana no le ha impedido su tributo a la carne pecadora. Ya sé que la comparación es insuficiente y traída por los pelos; pero es plásticamente reveladora para confirmar ese espíritu de la frontera, que alentaba en aquellos hombres, entre la sumisión y la transgresión. Vivirían en sus cabezas la dicotomía esencial de su inestable situación, que sería como en todas partes, el punto de partida de la renovación cultural, en la ruptura con el pasado, que Salamanca ha ido manteniendo con altibajos a lo largo de su historia, hasta convertirse en su signo más universal. Medio curas, medio seglares, mitad tradicionales, mitad novísimos, aquellos hombres encarnaban el destino general de la cultura, con la radical ambigüedad de sus presupuestos intelectuales. La cultura, perdidos los anclajes que la sostenían en el pasado, se debatía frente a los fantasmas de un porvenir incierto. Se insinuaba el movimiento histórico que se conocería con el nombre de Renacimiento, sin acabar de quemar las naves de la travesía del pasado. Esto es la frontera, en Salamanca y en cualquier otro lugar. Incertidumbre, inseguridad, hipótesis, apuestas fortuitas, opacidad del tiempo, incógnitas del lado de allá. La cultura desacralizada habría dejado un hueco, que aquellos escolares, revoltosos, inquietos, arriesgados e ingenuos tratarían de llenar, tanteando el hueco de su ignorancia, esforzándose en ver claro donde no había más que su deseo de acertar y la perentoria ansiedad de su angustia.

Pero aquellos prospectores de la nada sufrían además otra tensión fronteriza, que no podría menos de participar de la Salamanca universitaria y reforzar una de las singulares características de la cultura, que es su beligerancia, como adelantábamos antes. La Universidad de Salamanca fue el lugar de cita en el que fueron a recaer los Segundones de la nobleza feudal, que todavía coleaba, venida a menos y agarrada a sus privilegios, que tardaría siglos en soltar. Ya se sabe que en las familias residuales del feudalismo, con todas las matizaciones obligadas en el caso español, el Primogénito, el beneficiario del Mayorazgo, estaba destinado a la milicia, a la guerra, repitiendo el modelo ancestral de su clase, y el Segundogénito, para conservar los débitos 
de la tradición y asegurar la continuidad del honor familiar, debía seguir la carrera eclesiástica y buscar, al amparo de los estudios, el engrandecimiento de la fama del apellido y una plaza de primera línea en la eternidad celestial, con ayuda de algún obispado por medio. Esto echaba a la Universidad un aluvión de Segundones, marginados en sus casas, preteridos en los rangos domésticos, con todos los condicionamientos de su degradación social, incómodos en su papel, casi de adorno en una sociedad jerarquizada —caballeros, clérigos y campesinos-, tardomedieval, que había enfatizado la guerra. La cultura, para aquellos parias, sería el cauce de su desasosiego vital, la réplica de su obligado silencio frente al esplendor de las armas y la aceptación social de sus imágenes. La cultura será una vez más, en la Salamanca renaciente, en el decorado de su incipiente monumentalidad, respuesta dolorida, salvavidas de urgencia, protesta airada. Las Coplas satíricas de la época, como versión cutre de los exudados culturales, están llenas de los resentimientos de los Segundones, que cruzan el paisaje con el estigma de sus frustraciones. Algunos de ellos relacionados con la Universidad salmanticense. Víctimas de los estragos de otra frontera inaccesible, aquellos nobles de segunda fila impregnarían las aulas de su inconformismo beligerante, transfiriendo a su quehacer intelectual la poderosa imaginación de su rebeldía social, de la conciencia de la injusticia inmanente.

Algo semejante podríamos decir de otro colectivo, que frecuentó las aulas salmanticenses y encontró en la posibilidad de los estudios la salida, si no la redención, de su ostracismo social. Me estoy refiriendo naturalmente a los judíos, que buscaron en el estado eclesiástico, previo paso por las Escuelas universitarias, con Salamanca a la cabeza, la mejor manera de escapar a su destino de apestados, reducidos a sus guetos, objeto de masacres y persecuciones periódicas y confinados a menesteres subalternos, mal vistos y solamente tolerados. Los conocimientos universitarios les permitían integrarse en la comunidad de los cristianos, para hacerse olvidar sus orígenes vergonzantes. Estos hombres, salidos del submundo despreciado, con diversas alternativas de aceptación y de rechazo, poseedores de una rica tradición cultural, nunca abandonada del todo, conservarían la huella de sus antepasados y sentirían la extrañeza de las nuevas creencias, al otro lado de la frontera de su nueva vida, sobre el movedizo terreno de una inseguridad permanente, a la que la cultura le daría paréntesis de lucidez y tentaciones de desesperación. Serían siempre distintos, a los que la maledicencia popular daría un hedor especial, y vivirían en un cerco de desconfianzas, que alentaría sus ideas y propiciaría sus esfuerzos cul- 
turales por la asimilación, en una perpetua lucha contra sí mismos y contra el ambiente, habitantes de una frontera invisible pero operante. Tendrían el sentimiento trágico de la cultura y la irritación obstinada de los límites fronterizos, contra los que se cansarían de dar patadas. También ellos contribuyeron a dotar a Salamanca de la universalidad del saber y de la impotencia resentida de la ignorancia, anclados en la frontera de lo inefable.

Porque la cultura ha sido siempre y en todo lugar conflicto, búsqueda, renovación, ruptura y dramatismo. Los dos nombres simbólicos de este quehacer salmantino son dos hombres atormentados y difíciles, a contrapaso de sus conciudadanos, muy distintos por sus tragedias, pero muy iguales por los signos de sus vidas ajetreadas, que, para mayor coincidencia, ninguno de los dos era de Salamanca, con lo que añaden una razón más para reconocer el destino trágico de la cultura y su representatividad en la Universidad Salmantina, como lugar de combates culturales significativos. Teniendo en cuenta estos dos nombres, estamos en condiciones de entender mejor lo que el signo cultural de Salamanca ha sido - y probablemente sigue siendo, si no se emborracha de los tópicos del pensamiento único, que es la muerte de la culturaen su fidelidad a los imperativos de las exigencias culturales de siempre. Hay otros muchos más nombres, como Fernando de Rojas, Martín Martínez de Cantalapiedra o Ramón Salas, que pudieran servir para ejemplificar los avatares de esa frontera de la disidencia cultural, que resuma lo que puede significar Salamanca como placenta de la cultura. Pero son estos dos nombres, identificables a bote pronto, que no necesitan ni presentación ni justificación, por el relieve de su obra, los que mejor demuestran, por ser ambos criaturas culturales, con el peso de todos sus estigmas, la justeza de la apelación de la cultura para identificar, con todas sus características, lo que Salamanca es en el mapa universal de la cultura, que no se apoya fundamentalmente en su monumentalidad arquitectónica, ni en la nómina de sus estelares personajes literarios, ni en la caterva de los hombres importantes que pasaron por las aulas de su Universidad, ni por la fama de su nombre, sino por su constante testimonio de hacer de la cultura carne de la vida, encarnación del espíritu, como nuestros dos hombres, fray Luis de León y Miguel de Unamuno, vinieron a confirmar sobradamente, cada uno en su tiempo y con su imposible frontera delante.

Fray Luis representa, incluso más claramente que Unamuno, los avatares de la cultura y la dramática experiencia de la frontera, que la define. Su condición de judío no hizo más que agravar los problemas de su situación conflictiva. Disconforme con las imposiciones culturales 
de su tiempo, rebelde contra las arcaicas limitaciones al progreso de la lectura de las Sagradas Escrituras, defensor de la lengua castellana para el tratamiento de las cuestiones religiosas, acusado de peligrosas interpretaciones escriturarias, como Profesor de la Universidad, y de afirmaciones, rayanas en el escándalo eclesiástico, fray Luis exploró con imprudente decisión, según los códigos docentes de su tiempo, y con suicida contumacia, en época de denuncias inquisitoriales y susceptibilidades ortodoxas a flor de piel, la frontera de la heterodoxia, frente al contemporáneo pensamiento único. Sólo su portentosa erudición bíblica, justo el terreno de su especialidad, y el fuego de su pasión étnica, rodeado de enemistades y envidias, le salvaron de la hoguera, a cambio de una prolongada estancia en las cárceles de Valladolid. Pagó con su encarcelamiento y con su proceso, su tributo a la libertad cultural: tuvo que empeñarse en demostrar, con gran esfuerzo y con un pasmoso dominio de la lengua castellana, en «Los nombres de Cristo», que conocía a fondo, mejor que sus rivales, los textos sagrados y que, sin salirse de los cauces de la tradición cristiana, salvo la utilización egregia de la lengua vulgar, podía hablar del Dios encarnado, piedra de toque de la religión de sus antepasados judíos, como nadie, abrumando a sus acusadores con sus conocimientos profesorales, con Salamanca al fondo, y escribiendo la lengua más literaria y más bella de su tiempo, en un puro cultivo de la forma, que completaría y perfeccionaría su mensaje, en una insistencia verbal desbordada, en un extraordinario juego de artificio para callarles la boca a los que habían puesto en duda su fe, su anclaje cristiano, que era el punto de torsión de su inestabilidad conciliar. Probablemente para tapar con palabras el agujero devorador de la nada y de la incredulidad. Debemos pensar que ese espléndido alegato de su defensa, que va mucho más allá de sus necesidades tácticas ante los tribunales, que conforma «Los nombres de Cristo», es un admirable fruto cultural de primer orden, nacido de una angustiosa posición de condenado, a punto de saltarse la frontera.

Es obvio repetir que Unamuno, salmantino de elección, también Profesor y también incómodo en su tradición y con los códigos recibidos, fue igualmente una víctima de ese mismo espíritu de la frontera cultural, que Salamanca ampara y explica con su nombre. Mezcla explosiva de positivismo decimonónico y de idealismo finisecular, trasgresor a fondo y de por vida de consignas y de expectativas, contra esto y contra aquello, polemista en ejercicio continuado, iconoclasta hasta de sus propios iconos, desdeñoso de cualquier tipo de conformismo, de acomodación o de sosiego intelectual, Unamuno parecería destinado a simbolizar ese carácter bélicamente fronterizo de la cultura, que 
encontraba en Salamanca su lugar de afirmación y de expansión. Fue un exigente explorador de las tierras vírgenes de la frontera, desbrozadas por su genio y su tenacidad inagotable de expósito a la intemperie. Luchó contra el adocenamiento y la incultura, contra el cristianismo corruptor y contra la bobaliconería cientifista, contra la certidumbre de cualquier creencia y contra la paz de cualquier posición. Su dramática crisis del 97 tiene tanto de reacción psicosomática como de revuelta espiritual. Le obsesionó la nada y trató de ocultarla con la hojarasca de sus debates, con la firmeza de sus enemistades, con el monumento verbal de su obra. Ni creyó en Dios ni dejó de creer, desde un escepticismo, que rectificaba el mundo recibido y que le desesperaba, acuciándolo como un aguijón intolerable. Su desamparo, su fragilidad y su debilidad le empujaron a soñar con otra realidad contradictoria, a montar palabras sobre palabras, a crear cultura, un bien no fungible, en un avance a ciegas, en un tanteo de soluciones inviables. Salamanca fue su gran metáfora, duradera e insuficiente, inventada y observada, a partes iguales pensada y vivida. Con él la ciudad renovó su simbología cultural; él volvió a ocupar su puesto en la frontera variable, rehecha desde sus ruinas. Sufrió destierro, condena, rechazo ciudadano y tardíos reconocimientos oficiales. Encarnó la cultura y murió en la frontera de los nuevos tiempos, que le encontraron viejo para entenderlos. Salamanca le ayudó a definirse y le prestó sus imágenes para que las vulnerara. El mismo se preguntó muchas veces: Y «isi del otro lado de la frontera no hubiera nada?». Salamanca fue su respuesta. 